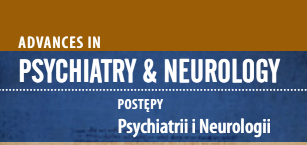

Correspondence to/Adres do korespondencji:

Julita Kuczyńska

Department of Pharmacology

Institute of Psychiatry and Neurology

9 Sobieskiego St.

02-957 Warsaw, Poland

e-mail: jkuczynska@ipin.edu.pl

Submitted/Otrzymano: 04.08.2021

Accepted/Przyjęto do druku: 01.10.2021

\section{Individualization of lithium therapy based on the monitoring of its level in saliva}

\author{
Indywidualizacja terapii litem \\ na podstawie monitorowania w ślinie
}

\author{
Julita Kuczyńska (D), Alicja Zakrzewska-Sito (D) \\ Department of Pharmacology, Institute of Psychiatry and Neurology, Warsaw, \\ Poland
}

\begin{abstract}
Purpose: Bipolar disorder (BD) is a mental disorder that affects approximately $2-3 \%$ of the population. The mainstay of treatment in bipolar disorder is lithium, which has also found an important application in the potentiation of antidepressants in drug-resistant depression, in the course of both bipolar disorder and recurrent depressive disorders.

Views: The narrow therapeutic range of lithium and the frequent side effects it causes necessitates the monitoring of its concentration in the blood, which requires the periodic presence of the patient in a clinical laboratory. This is costly and inconvenient for patients, and is a common obstacle for psychiatrists who are reluctant to prescribe this effective drug precisely because of the inconvenience of having to monitor blood levels. If regular monitoring of lithium levels could be carried out without the need to puncture the vein and visit a clinic it would save time for both patients and healthcare professionals, avoid discomfort, and make difficult-to-reach patients easier to manage.

Conclusions: Saliva in the monitoring of the lithium level is a promising biological material and offers the possibility to quickly estimate the individual lithium dosage for a specific patient which will provide the required therapeutic level. Saliva can be collected at home without the involvement of qualified personnel. Providing a more convenient and effective means of monitoring lithium therapy (e.g. the proposed non-invasive saliva level test) would enable safer, more effective therapy (more likely to maintain therapeutic blood levels) and an individualized therapeutic approach to a patient.
\end{abstract}

Key words: lithum, saliva, drug monitoring.

\title{
Streszczenie
}

Cel: Choroba afektywna dwubiegunowa (ChAD) jest zaburzeniem psychicznym występującym u około 2-3\% populacji. Podstawę leczenia w ChAD stanowi lit. Lit znalazł też ważne zastosowanie w potencjalizacji leków przeciwdepresyjnych w wypadku depresji lekoopornej, w przebiegu zarówno ChAD, jak i zaburzeń depresyjnych nawracających.

Poglądy: Wąski zakres terapeutyczny dla litu oraz częste działania niepożądane wymagają konieczności monitorowania jego stężenia we krwi, co wymaga okresowej obecności pacjenta w laboratorium klinicznym. Jest to kosztowne i niedogodne dla chorych oraz stanowi częstą przeszkodę dla lekarzy psychiatrów, którzy bardzo niechętnie ordynują ten skuteczny lek, właśnie z uwagi na niedogodności związane z koniecznością monitorowania jego stężenia we krwi. Gdyby można było prowadzić regularne monitorowanie stężenia litu bez konieczności nakłuwania żyły i wizyty pacjenta w klinice, zaoszczędziłoby to czas zarówno pacjentów, jak i personelu medycznego, pozwoliłoby na uniknięcie dyskomfortu i łatwiejszą kontrolę trudno dostępnych pacjentów.

Wnioski: Ślina w monitorowaniu stężenia litu jest obiecującym materiałem biologicznym i daje możliwość szybkiego oszacowania dla konkretnego pacjenta indywidualnego dawkowania tego leku, które zapewni wymagane stężenie terapeutyczne. Ślina może być pobierana w warunkach domowych bez angażowania wykwalifikowanego personelu. Dostarczenie wygodniejszych i skuteczniejszych sposobów monitorowania terapii litem (np. proponowane bezinwazyjne badanie stężenia w ślinie) umożliwiłoby bezpieczniejszą, bardziej skuteczną terapię (większe prawdopodobieństwo utrzymywania stężenia terapeutycznego we krwi) danego pacjenta. Słowa kluczowe: lit, ślina, monitorowanie leku. 


\section{INTRODUCTION}

Since its introduction to psychiatry in 1949 , lithium has revolutionized the treatment of affective disorders $[1,2]$. The narrow therapeutic range of lithium and the frequent side effects it causes require monitoring of its concentration. Saliva is a promising biological material that can enable the quick estimation of an individual lithium dose for a particular patient. The aim of the study was to present the relevant research on the possibility of using saliva for lithium determination in humans and the importance of this matrix in the individualization of therapy. Search terms (as used in EMBASE, PubMed (NLM) and MEDLINE) included "lithium AND determination in saliva", "lithium AND correlation saliva/plasma". All relevant articles published between 1960 and May 2021 were included for analysis. Animal-based studies and duplicates were excluded.

\section{THE METABOLIZATION OF LITHIUM}

Lithium ions are almost completely absorbed from the gastrointestinal tract. Absorption is complete in about 8 hours, with peak concentrations being reached $2-4$ hours after oral administration. The volume of distribution is approximately $0.7 \mathrm{l} / \mathrm{kg}$; lithium does not bond to proteins. As a cation, it is not metabolized and is almost entirely (about 95\%) excreted in the urine (small amounts of 4-5\% are excreted in sweat). The biological half-life is long, approximately 19 hours, and also shows large individual differences (13-33 hours), depending on the patient's age, kidney condition and the duration of lithium treatment $[3,4]$.

\section{THERAPEUTIC LITHIUM LEVEL}

Although lithium is very effective, its use is limited due to its narrow therapeutic range and frequent occurrence of concentration-dependent side effects. Recent recommendations of the International Society of Bipolar Disorder (ISBD) and International Group for the Study of Lithium-Treated Patients (IGSLI) working group recommend maintaining lithium concentration for prophylactic purposes at $0.60-0.80 \mathrm{mmol} / \mathrm{l}$. In the case of a good effect and worse somatic tolerance, the acceptable level is $0.40-0.60 \mathrm{mmol} / \mathrm{l}$, while with a non-optimal effect and good tolerance, the lithium dose can be increased to $0.80-1.00 \mathrm{mmol} / \mathrm{l}[5]$. The same recommendations were adopted for children and adolescents. For the elderly, a more conservative approach was advocated: serum lithium levels should be in the range of $0.40-0.60 \mathrm{mmol} / \mathrm{l}$, with the option to peak at 0.70 or $0.80 \mathrm{mmol} / \mathrm{l}$ at the age of $65-79$ years and up to a maximum of $0.70 \mathrm{mmol} / \mathrm{l}$ over the age of 80 [5].
Adverse effects of lithium may be present even when concentrations are well within the recommended therapeutic range [4]. The toxic effects of lithium usually set in when plasma levels go beyond $1.5 \mathrm{mmol} / \mathrm{l}$ [2]. Mild symptoms (serum lithium concentration between $1.5-2.5 \mathrm{mmol} / \mathrm{l}$ ) include nausea, vomiting, lethargy, tremor, and fatigue. Moderate intoxication (serum lithium concentration between $2.5-3.0 \mathrm{mmol} / \mathrm{l}$ ) can cause confusion, agitation, delirium, tachycardia, and hypertonia. Serum concentrations above $3.0 \mathrm{mmol} / \mathrm{l}$ are often associated with severe symptoms (coma, seizures, hyperthermia, and hypotension) [6]. Toxicity may occur suddenly as a result of rapid accumulation of lithium (overdose, drug interactions and physical illness) or due to cumulative high concentrations during long-term therapy. The presence of side effects contributes to worse treatment outcomes and non-compliance with medical recommendations [7]. For these reasons, lithium requires frequent monitoring of its blood levels.

International guidelines recommend that patients taking lithium should be monitored at least every 3-6 months [8], even more frequently after dose changes, and in the event of a recurrence of the disease or symptoms of poisoning $[8,9]$. After initiation, the serum lithium level should be obtained (12 hours after last dose) twice a week until there is clinical response or the lithium level reaches $0.7-1.0 \mathrm{mmol} / \mathrm{l}[10]$. In the use of lithium, it is necessary to take into account the somatic state of the patient, all medications taken, and inter- and intra-individual variability. Therefore, factors that influence renal function, such as age, dehydration, caffeine and heavy/chronic alcohol consumption, sodium balance, hemodynamics, serum creatinine levels, and body mass index (BMI) have a potential effect on serum lithium levels [11-13].

Knowledge of the concentration of lithium ions is essential for the diagnosis of lithium poisoning and for emergency treatment. An important role in lithium therapy and clinical supervision is played by the patients themselves. The patient should be aware and able to recognize unfavorable symptoms of the lithium therapy [14]. The clinical condition of the patient may lead to differences in the pharmacokinetics of lithium. The level of lithium decreases in patients during hypomania, the level remains constant in the normal state and increases in depression [15].

\section{OPINION}

The narrow therapeutic range for lithium and the frequent side effects it causes necessitates the monitoring of its concentration in the blood, which requires the periodic presence of the patient in a clinical laboratory. Therefore, it is costly and inconvenient for patients, and is a frequent obstacle for psychiatrists who are very reluctant to prescribe this effective drug, precisely due to 
the inconvenience associated with the need to monitor its level in the blood. It is worth emphasizing that, properly conducted and monitored, lithium treatment in bipolar disorder results in excellent lithium responders in about $1 / 3$ of patients and remission of the disease lasting up to decades. However, in case of insufficient effectiveness, it is recommended to add another, additional mood stabilizer. Therefore, in most patients with bipolar disorder combined therapy is used, in which lithium is an important element. In the case of using additional mood stabilizing drugs, due to the risk of interactions it is even more important to monitor its concentration in the blood. After the introduction of new mood stabilizer drugs to the market in the 1970s and 1980s, the interest in lithium treatment and its monitoring techniques decreased significantly. In the following years, the usefulness of other, newer mood stabilizers was called into question and their limited effectiveness and side effects noted. This has resulted in a renewed interest in one of the oldest drugs in psychiatry in recent years. Lithium has also found an important application in the potentiation of antidepressants in drug-resistant depression, in the course of both bipolar disorder and recurrent depressive disorders. Lithium's potentiating of the action of antidepressants may be the second, after bipolar relapse prevention, indication for its administration. All this translates into the return of lithium to treatment observed in recent years and the intensified search for new methods of monitoring and personalizing therapy involving the use of this drug.

If regular monitoring of lithium levels could be carried out without the need to puncture the vein and visit a clinic, it would save time for both patients and healthcare professionals, avoid discomfort, and make difficultto-reach patients easier to manage. As an alternative to the currently used lithium therapy monitoring procedure, determination of the lithium concentration in saliva has been proposed.

\section{DETERMINATION OF LITHIUM LEVEL IN SALIVA}

The use of saliva in diagnostics is becoming increasingly popular and is an attractive alternative to other invasive, time-consuming and complicated diagnostic methods. From an ethical point of view, saliva can be considered the best material for human research.

It can be collected at home without the involvement of qualified personnel. As a biological fluid, saliva does not coagulate, it is stable for diagnostic purposes for 24 hours at room temperature and for 7 days at $4^{\circ} \mathrm{C}$. Due to the greater comfort it can provide in the monitoring of this therapy, measurements of lithium concentration in saliva could be carried out more frequently than is currently prescribed for traditional blood concentration determinations. By using this matrix it would be possible to administer more accurate and patient-specific dosages of this drug. Providing more convenient and effective ways of monitoring lithium therapy (i.e. the proposed non-invasive saliva level test) would enable safer (reduced risk of side effects and poisoning), more effective therapy (higher probability of maintaining the therapeutic level in the blood), and an individualized therapeutic approach to a given patient.

Early lithium concentration studies suggested the use of saliva as an alternative to blood monitoring in people $[16,17]$. Several studies have shown significant correlations between saliva and serum lithium values (i.e. between 0.70 and 0.90$)$ in adult patients $[3,18-30]$ and children [31-33] treated with lithium carbonate (Table 1).

Gałuszko-Węgielnik et al. [34] reviewed published studies on the use of saliva as an alternative matrix to monitor blood lithium levels. However, the data in the literature did not provide a conclusive picture. The limitations of the researches performed were the small sample size, different saliva collection techniques, the use of older methods of lithium quantification, and the lack of consideration of lifestyle variables. Few studies have analyzed the within-patient relationship between saliva and serum lithium levels [22]. Previous studies have also shown that body weight, serum creatinine, serum potassium, and age correlate with serum lithium levels $[35,36]$.

In 2021, Parkin et al. [30] analyzed the relationship between saliva and serum lithium levels in a multicenter cohort of patients taking lithium and confirmed a strong saliva/serum correlation $(\geq 0.74)$. The correlation was assessed on 169 matched saliva and serum samples from 75 people recruited from two different centers, and strongly confirmed the usefulness of using saliva to monitor lithium levels. Parkin et al. [30] conducted the largest and most integrated study confirming the usefulness of saliva as an appropriate biological fluid for the therapeutic monitoring of lithium. The authors showed that taking into account the daily lithium dose, dosing regimen, smoking, and diabetes mellitus, the power of saliva in predicting serum levels could be increased. In this study, as in the studies by Mathew et al. [37] and Xu et al. [38], no effect of BMI and creatinine on the serum lithium level was observed. A statistically significant correlation was found between the serum potassium level and the level of lithium in saliva and serum, whereas no such relationship was found for the saliva/plasma lithium level.

Parkin et al. [30], after identifying and considering a number of clinical and lifestyle factors influencing lithium levels, showed that saliva can be an alternative non-invasive biological matrix for lithium monitoring. It was also found that the lithium saliva/serum ratio is positively correlated with age. The glomerular filtration rate decreases with age [39] and the elderly may become more sensitive to lithium treatment. These people more 
Table 1. Summary of research results "The relationship between serum and salivary concentrations of lithium"

\begin{tabular}{|c|c|c|c|c|}
\hline Reference & Patients, $n$ & Stimulated & $\begin{array}{c}R \\
\text { Intrasubject analysis }\end{array}$ & $\begin{array}{l}\text { Possible replacement serum } \\
\text { to saliva }\end{array}$ \\
\hline Spring and Sprintes (1969) (16) & 5 & No/Yes & 0.92 & Yes \\
\hline Shopsin et al. (1969) (17) & 25 & Yes & 0.85 & Yes \\
\hline Verghese et al. (1977) (18) & 24 & No & 0.88 & Yes \\
\hline Preskorn et al. (1978) (19) & 25 & No data & 0.79 & Yes \\
\hline Man (1979) (20) & 30 & Yes & 0.73 & Yes \\
\hline Othmer et al. (1979) (21) & 25 & No data & 0.89 & Yes \\
\hline Rosman et al. (1980) (22) & 11 & No/Yes & $0.72-0.94$ & Yes \\
\hline Nataraj et al. (1981) (23) & 28 (140 samples) & Yes & 0.71 & No \\
\hline Bowden et al. (1982) (24) & 40 & Yes & 0.83 & Yes \\
\hline Khare et al. (1983) (25) & 60 & Yes & 0.73 & Yes \\
\hline Ben-Aryeh et al. (1984) (26) & $\begin{array}{l}78 \text { and } 49 \text { (healthy } \\
\text { volunteers) }\end{array}$ & Yes & No data & Yes \\
\hline Perry et al. (1984) (31) & 21 (children) & No data & 0.83 & No (unclear) \\
\hline Vitiello et al. (1987) (32) & 9 (children) & Yes & 0.93 & limited \\
\hline Obach et al. (1988) (27) & 8 healthy volunteers & Yes & 0.81 & Yes \\
\hline McKeage et al. (1989) (28) & 28 & No data & $\begin{array}{l}\text { High levels of inter-individual } \\
\text { and intra-individual variation } \\
\text { were found in plasma/saliva } \\
\text { and erythrocyte/saliva lithium } \\
\text { level ratios }\end{array}$ & No \\
\hline Spencer et al. (1990) (33) & 30 (children) & No data & $\begin{array}{l}\text { At optimal dose } 0.78 \\
\text { and overall } 0.83\end{array}$ & Limited \\
\hline Serdarević et al. (2006) (3) & 25 & No & 0.74 & Yes \\
\hline Shetty et al. (2012) (29) & 50 & No & $\begin{array}{c}0.70 \\
\text { (0.78 - females; } 0.67 \text { - males) }\end{array}$ & $\begin{array}{l}\text { No (more studies are needed } \\
\text { in this domain to establish } \\
\text { salivary therapeutic monitoring } \\
\text { as a feasible option } \\
\text { for patients in lithium } \\
\text { carbonate therapy) }\end{array}$ \\
\hline Parkin et al. (2021) (30) & 75 & No & 0.74 & Yes \\
\hline
\end{tabular}

often have many comorbidities that may have an undefined effect on the distribution of lithium in the body and more often use drugs that may interfere with its elimination, such as hydrochlorothiazide, NSAIDs and ACE inhibitors and angiotensin receptor antagonists [13]. Earlier studies suggest that the prediction of within-patient lithium concentration may only be limited to younger populations, as the saliva/serum lithium correlation varies greatly among older adults. However, these studies did not take into account a number of factors that may affect the levels of lithium in biological fluids in the elderly.

Parkin et al. [30] also suggest that for patients over 55 years of age the median saliva/serum lithium concentration from three previous visits rather than one should be used to determine the lithium dose from saliva samples. A limitation of this study was that it included a small number of patient samples in the higher range of serum lithium concentration $(\geq 1.00 \mathrm{mmol} / \mathrm{l})$. The inter-individual predicted concentrations and actual concentrations varied by more than $0.20 \mathrm{mmol} / \mathrm{l}$. However, when the pre- dicted and actual serum lithium levels were compared, based on a single saliva/serum result and using the mean inter-individual ratio of the three visits, the predicted serum concentration was $<0.10 \mathrm{mmol} / \mathrm{l}$ from the observed level in $75 \%$ of patients. The authors also included patients in their study who did not comply with their recommended dose of lithium or who missed a scheduled dose. The daily dose of lithium has a significant influence on the correlation between saliva and plasma, and better results would probably be obtained only by taking into account patients who use the drugs in accordance with the recommendations. Significant influence on the saliva/ plasma correlation had an impact on the daily dose of lithium, so they would probably obtain better results if only patients who use the medication as prescribed were included. Note that the lithium prediction models included samples from patients whose doses were changed at subsequent visits, suggesting that dose changing or adjustment will not significantly affect the use of saliva to predict serum lithium levels. As early as 1980, 
Rosman et al. [22] found that the inter-subject model would work best for clinically stable patients meeting the medical requirements and requiring testing only every 3-6 months. In analyzing previous studies, despite differences in the methods of collecting and quantifying lithium in saliva it is observable that most of them reported a saliva/serum lithium correlation similar to that observed in the study by Parkin et al. [3, 13, 18, 21, 28-30].

Serdarević et al. [3], comparing the lithium saliva/ serum correlation 2 and 12 hours after a most recent dose, observed a higher correlation 2 hours after taking the drug. Due to the difference in the pharmacokinetics of lithium in saliva and serum, the time of the last dose administration was decisive $[3,27]$. No differences were observed between the concentrations of lithium ions in men and women, unlike another study which found a higher correlation between the concentrations of lithium in saliva and serum in women [29]. In general, the concentration of lithium in saliva is about 2-3 times higher than in serum [40, 41]. This can be explained by the slower removal of lithium ions from saliva than from serum. The higher concentration of lithium in saliva indicate that it is actively transported into saliva $[3,42]$.

Due to discrepancies in the effectiveness of the use of saliva in lithium-monitored therapy, methods of saliva collection and processing were analyzed. Centrifugation or the use of a dialysis filter to separate the water and mucous fractions of saliva affects the accuracy of lithium measurements and increases the saliva/plasma correlation [43].

When it comes to collecting saliva samples for the determination of lithium levels, monitoring of the therapy should take into account several factors, e.g. xerostomia, smoking, oral diseases, tooth brushing and diet [34]. As a biological material, saliva does not require specific sampling methods. Tadeusiak et al. [44] used the Salivette device for collecting samples, which allowed for unstimulated saliva accumulation. Previously, it was shown that the level of lithium in unstimulated saliva is directly proportional to the concentration in serum. While stimulating saliva flow with a sweet or sour tablet, the level of lithium in the parotid saliva was not related to the flow rate [45]. The saliva/serum ratio of lithium remained constant over the 100 -fold concentration range for at least 3 months and was not affected by 10 -fold changes in flow rate [46]. Changing from a lying to an upright position does not affect the level of lithium in the saliva; a correlation between urine lithium clearance and saliva clearance in the supine position has been noted, but not in the upright position [47].

The most suitable analytical techniques for the routine analysis of lithium in samples of a very different nature are offered by atomic spectrometry, including atomic absorption spectrometry (ASA or AAS - atomic absorption spectrometry) with flame atomization (FAAS - flame atomic absorption spectrometry) and in a graphite furnace (GFAAS - graphite furnace atomic absorption spectroscopy), flame atomic emission spectrometry (FAES), excited plasma emission spectrometry (IPC-AES also known as IPC-OEC), and inductively coupled plasma mass spectrometry (ICP-MS). The methods of determination must be subject to strict quality control. There is now a formal requirement for clinical laboratories to demonstrate through validation that their assay methods produce reliable results that meet the expected quality.

\section{CONCLUSIONS}

It has been shown that lithium can be measured in the saliva of patients. Moreover, it is a non-invasive and cost-effective approach to monitoring lithium levels. The collection process does not require trained personnel, and the ability of patients to produce saliva samples at home would enable them to collect the sample at a time that is not only convenient for them, but may also be better coordinated with their daily dose, times of taking other medications and/or meals. These features can directly translate into more frequent and better lithium monitoring in both outpatients and inpatients. In the case of outpatients, saliva sampling may allow for collection at home without making an appointment at their clinic. This is important because the use of lithium is based on reaching a minimum level of it in the blood, which is difficult to pinpoint accurately during a visit to a clinic. For hospitalized patients, salivary lithium levels can also be used to better optimize and synchronize trough levels, as saliva sampling would not be restricted to the ward sampling schedule. Moreover, it has been observed that hospitalized patients consent to saliva collection much more frequently than blood donation. This feature is not limited to inpatients, as many outpatients, especially those in a manic state, also refuse to collect blood.

The saliva/serum lithium level correlation found in various studies, in most patients, makes it possible to develop and implement a point-of-care (POC) device for determining lithium in saliva. In the era of personalized medicine, a saliva-based lithium POC test would be of great value as it would optimize treatment protocols for home retrieval as well as patient compliance in clinics. In addition, the POC saliva test would provide the basis for future technical innovations enabling lithium monitoring with point-of-care devices that could send data directly to the patient's healthcare provider. The implementation of such devices for the determination of saliva samples is already underway [48].

In 2005, the FDA approved the use of a finger-prick in-office test and the determination of serum lithium levels in doctor's surgeries. The use of this test may reduce the frequency and need for venipuncture; however, it should be remembered that this is not very accurate method. 
Saliva in the monitoring of lithium levels is a promising biological material and offers the possibility to estimate the individual lithium dosage, by means of a simple patient test, that will give the required therapeutic level. However, this issue requires further research based on current data, including the establishment of a saliva collection procedure, sampling at a specific time from the last lithium dose, and taking into account inter-individual or intra-individual differences.

Conflict of interest/Konflikt interesu

Absent./Nie występuje.

Financial support/Finansowanie

Absent./Nie występuje.

\section{References/Piśmiennicłwo}

1. Cipriani A, Hawton K, Stockton S, Geddes JR. Lithium in the prevention of suicide in mood disorders: updated systematic review and meta-analysis. BMJ 2013; 346: f3646.

2. Rybakowski J. Lithium treatment - the state of the art for 2020. Psychiatr Pol 2020; 54: 1047-1066.

3. Serdarević N, Kozjek F, Malesic I. Saliva and serum lithium monitoring in hospitalized patients and possibility to replace serum to saliva. Bosn J Basic Med Sci 2006; 6: 32-35.

4. Oruch R, Elderbi MA, Khattab HA, Pryme IF, Lund A. Lithium: a review of pharmacology, clinical uses, and toxicity. Eur J Pharmacol 2014; 740: 464-473.

5. Nolen WA, Licht RW, Young AH, Malhi GS, Tohen M, Vieta E, et al.; ISBD/IGSLI Task Force on the treatment with lithium. What is the optimal serum level for lithium in the maintenance treatment of bipolar disorder? A systematic review and recommendations from the ISBD/IGSLI Task Force on treatment with lithium. Bipolar Disord 2019; 21: 394-409.

6. Hedya SA, Avula A, Swoboda HD. Lithium Toxicity. StatPearls - NCBI Bookshelf; 2021.

7. Murru A, Pacchiarotti I, Amann B, Nivoli A, Vieta E, Colom F. Treatment adherence in bipolar I and schizoaffective disorder, bipolar type. J Affect Disord 2013; 151: 1003-1008.

8. Ng F, Mammen OK, Wilting I, Sachs GS, Ferrier IN, Cassidy F, et al. The International Society for Bipolar Disorders (ISBD) consensus guidelines for the safety monitoring of bipolar disorder treatments. Bipolar Disord 2009; 11: 559-595.

9. Kirkham E, Bazire S, Anderson T, Wood J, Grassby P, Desborough JA. Impact of active monitoring on lithium management in Norfolk. Ther Adv Psychopharmacol 2013; 3: 260-265.

10. Khan SA, Anand A, D'Souza DC. Lithium carbonate. Encyclopedia of the Neurological Sciences. Elsevier Science (USA); 2003, p. 803-810.

11. Finley PR, Warner MD, Peabody CA. Clinical relevance of drug interactions with lithium. Clin Pharmacokinet 1995; 29: 172-191.

12. Thomsen K, Schou M. Avoidance of lithium intoxication: advice based on knowledge about the renal lithium clearance under various circumstances. Pharmacopsychiatry 1999; 32: 83-86.

13. Sproule BA, Hardy BG, Shulman KI. Differential pharmacokinetics of lithium in elderly patients. Drugs Aging 2000; 16: 165-177.

14. Amdisen A. Clinical features and management of lithium poisoning. Med Toxicol Adverse Drug Exp 1988; 3: 18-32.

15. Couffignal C, Chevillard L, El Balkhi S, Cisternino S, Declèves X. The pharmacokinetics of lithium. In: Malhi GS, Masson M, Bellivier F (eds.). The Science and Practice of Lithium Therapy. Cham: Springer International; 2017, p. 25-53.

16. Spring KR, Spirtes MA. Salivary excretion of lithium. I. Human parotid and submaxillary secretions. J Dent Res 1969; 48: 546-549.

17. Shopsin B, Gershon S, Pinckney L. The secretion of lithium in human mixed saliva: effects of ingested lithium on electrolyte distribution in saliva and serum. Int Pharmacopsychiatry 1969; 2: 148-169.

18. Verghese A, Indrani N, Kuruvilla K, Hill PG. Usefulness of saliva lithium estimation. Br J Psychiatry 1977; 130: 148-150.

19. Preskorn SH, Abernethy DR, McKnelly WV Jr. Use of saliva lithium determinations for monitoring lithium therapy. J Clin Psychiatry 1978; 39: 756-758.

20. Man PL. Correlation of saliva and serum lithium. Psychosomatics 1979; 20: 758-759.

21. Othmer E, Powell B, Piziak VK, Preskorn SH. Prospective use of saliva lithium determinations to monitor lithium therapy. J Clin Psychiatry 1979; 40: 525-526. 
22. Rosman AW, Sczupak CA, Pakes GE. Correlation between saliva and serum lithium levels In manic-depressive patients. Am J Hosp Pharm 1980; 37: 514-518.

23. Nataraj GS, Bhat VK. Reliability of saliva lithium level-a prospective study. Indian J Psychiatry 1981; 23: 115-119.

24. Bowden CL, Houston JP, Shulman RS, Clothier JM. Clinical utility of salivary lithium concentration. Int Pharmacopsychiatry 1982; 17: 104-113.

25. Khare CB, Sankaranarayanan A, Goel A, Khandelwal SK, Srinivasa Murthy R. Saliva lithium levels for monitoring lithium prophylaxis of manic depressive psychosis. Int J Clin Pharmacol Ther Toxicol 1983; 21: 451-453.

26. Ben-Aryeh H, Laor R, Szargel R, Gutman D, Naon H, Pascal M, Hefetz A. Saliva for monitoring of patients with primary affective disorders. Isr J Med Sci 1984; 20: 197-201.

27. Obach R, Borja J, Prunonosa J, Valles JM, Torrent J, Izquierdo I, Jane F. Lack of correlation between lithium pharmacokinetic parameters obtained from plasma and saliva. Ther Drug Monit 1988; 10: 265-268.

28. McKeage MJ, Maling TJ. Saliva lithium: a poor predictor of plasma and erythrocyte levels. N Z Med J 1989; 102: 559-560.

29. Shetty SJ, Desai PB, Patil NM, Nayak RB. Relationship between serum lithium, salivary lithium, and urinary lithium in patients on lithium therapy. Biol Trace Elem Res 2012; 147: 59-62.

30. Parkin GM, McCarthy MJ, Thein SH, Piccerillo HL, Warikoo N, Granger DA, Thomas EA. Saliva testing as a means to monitor therapeutic lithium levels in patients with psychiatric disorders: identification of clinical and environmental covariates, and their incorporation into a prediction model. Bipolar Disord 2021; 23: 679-688.

31. Perry R, Campbell M, Grega DM, Anderson L. Saliva lithium levels in children: their use in monitoring serum lithium levels and lithium side effects. J Clin Psychopharmacol 1984; 4: 199-202.

32. Vitiello B, Behar D, Ryan P, Malone R, Delaney MA. Saliva lithium monitoring. J Am Acad Child Adolesc Psychiatry 1987; 26: 812-813.

33. Spencer EK, Campbell M, Adams P, Perry R, Choroco MC, Padron-Gayol M, Small AM. Saliva and serum lithium monitoring in hospitalized children. Psychopharmacol Bull 1990; 26: 239-243.

34. Gałuszko-Węgielnik M, Jakuszkowiak-Wojten K, Wiglusz MS, Szarmach J, Włodarczyk A, Herstowska M, Cubała WJ. Lithium therapeutic dose monitoring in human saliva. Psychiatr Danub 2017; 29: 361-364.

35. Sims A, White A, Garvey K. Problems associated with the analysis and interpretation of saliva lithium. Br J Psychiatry 1978; 132: 152-154.

36. Yukawa E, Nomiyama N, Higuchi S, Aoyama T. Lithium population pharmacokinetics from routine clinical data: role of patient characteristics for estimating dosing regimens. Ther Drug Monit 1993; 15: 75-82.

37. Mathew B, Rao JM, Sundari U. Lithium-induced changes in the body mass index. Acta Psychiatr Scand 1989; 80: 538-540.

38. Xu YY, Xia QH, Liang J, Cao Y, Shan F, Liu Y, et al. Factors related to lithium blood concentrations in Chinese Han patients with bipolar disorder. Neuropsychiatr Dis Treat 2019; 15: 1929-1937.

39. Weinstein JR, Anderson S. The aging kidney: physiological changes. Adv Chronic Kidney Dis 2010; 17: 302-307.

40. Sims A. Monitoring lithium dose levels: estimation of lithium in saliva. Johnson FN (ed.). Handbook of Lithium Therapy. Springer England; 1980, p. 200-205.

41. Santo C, Carvalho T. Determination of serum lithium: comparison between atomic emission and absorption spectrometry methods. Jornal Brasileiro de Patologia e Medicina Laboratorial 2014; 50: 12-19.

42. Langman JL. The use of oral fluid for therapeutic drug manangement. Ann NY Acad Sci 2007; 1098: 145-166.

43. El-Mallakah RS, Linder M, Valdes Jr R, Looney S. Dialisys of saliva improves accuracy of saliva lithium determinations. Bipolar Disord 2004; 6: 87-89.

44. Tadeusiak W, Krawczyński MJ, Balicka B. The possibility of replacing blood serum with sputum for monitoring of therapy with lithium carbonate. Pol Tygodnik Lek 1992; 47: 1029-1030.

45. Sankaranarayanan A, Goel A, Pant V. Variation in the relationship between serum and saliva lithium levels. Int J Clin Pharmacol Ther Toxicol 1985; 23: 365-366.

46. Groth U, Prellwitz W, Jahnchen E. Estimation of pharmacokinetic parameters of lithium from saliva and urine. Clin Pharmacol Ther 1974; 16: 490-497.

47. Shimizu M, Smith DF. Relationship between clearance of lithium, potassium and sodium in human mixed saliva. Int Pharmacopsychiatry 1978; 13: 34-38.

48. Goldoni R, Farronato M, Connelly ST, Tartaglia GM, Yeo WH. Recent advances in graphene-based nanobiosensors for salivary biomarker detection. Biosens Bioelectron 2021; 171: 112723. 